University of Nebraska - Lincoln

DigitalCommons@University of Nebraska - Lincoln

Publications, Agencies and Staff of the U.S.

Department of Commerce

U.S. Department of Commerce

2012

\title{
Pharmaceuticals and personal care products (PPCPs) in treated wastewater discharges into Charleston Harbor, South Carolina
}

Melanie Lea Hedgespeth

College of Charleston, Melanie.Hedgespeth@biol.lu.se

Yelena Sapozhnikova

USDA-ARS

Paul Pennington

NOAA

Allan Clum

Mount Pleasant Waterworks

Andy Fairey

Charleston Water System

See next page for additional authors

Follow this and additional works at: https://digitalcommons.unl.edu/usdeptcommercepub

Part of the Environmental Sciences Commons

Hedgespeth, Melanie Lea; Sapozhnikova, Yelena; Pennington, Paul; Clum, Allan; Fairey, Andy; and Wirth, Edward, "Pharmaceuticals and personal care products (PPCPs) in treated wastewater discharges into Charleston Harbor, South Carolina" (2012). Publications, Agencies and Staff of the U.S. Department of Commerce. 383

https://digitalcommons.unl.edu/usdeptcommercepub/383

This Article is brought to you for free and open access by the U.S. Department of Commerce at DigitalCommons@University of Nebraska - Lincoln. It has been accepted for inclusion in Publications, Agencies and Staff of the U.S. Department of Commerce by an authorized administrator of DigitalCommons@University of Nebraska - Lincoln. 


\section{Authors}

Melanie Lea Hedgespeth, Yelena Sapozhnikova, Paul Pennington, Allan Clum, Andy Fairey, and Edward Wirth 


\title{
Pharmaceuticals and personal care products (PPCPs) in treated wastewater discharges into Charleston Harbor, South Carolina
}

\author{
Melanie Lea Hedgespeth a,*, Yelena Sapozhnikova ${ }^{\text {b,1 }}$, Paul Pennington ${ }^{\text {c }}$, Allan Clum ${ }^{\mathrm{d}}$, \\ Andy Fairey ${ }^{\mathrm{e}}$, Edward Wirth ${ }^{\mathrm{c}, \mathrm{f}, * *}$ \\ a College of Charleston, 205 Fort Johnson Rd., Charleston, SC 29412, USA \\ b JHT Inc., (Contractor to NOAA), 331 Fort Johnson Rd., Charleston, SC 29412, USA \\ 'Center for Coastal Environmental Health and Biomolecular Research, NOAA, NOS, NCCOS, 219 Fort Johnson Rd., Charleston, SC 29412, USA \\ d Mount Pleasant Waterworks, 1619 Rifle Range Road Mount Pleasant, SC 29464, USA \\ e Charleston Water System, 103 St. Philip Street, Charleston, SC 29402 USA \\ f Center for Human Health Risk, Hollings Marine Laboratory, NOAA, NOS, NCCOS, 331 Fort Johnson Rd., Charleston, SC 29412, USA
}

\section{H I G H L I G H T S}

- First known study to examine PPCPs in the South Atlantic Bight.

- Examines seasonal and regional trends of PPCP concentrations in a coastal system.

- Eleven PPCPs were quantified in WWTP influent, 9 in effluent, and 7 in surface water.

- Removal from aqueous phase in wastewater treatment is generally estimated to be $>86 \%$.

- Greater detection in winter may have been related to colder temperatures.

\section{A R T I C L E I N F O}

\section{Article history:}

Received 15 February 2012

Received in revised form 28 May 2012

Accepted 23 July 2012

Available online 17 August 2012

\section{Keywords:}

Pharmaceutical

Hormone

EPA Method 1694

Influent

Effluent

Estuary

\begin{abstract}
A B S T R A C T
This study assessed seasonal and regional trends of pharmaceuticals and personal care products (PPCPs) detected in monthly samples from two local wastewater treatment plants (WWTPs) in Charleston, South Carolina, USA, over the period of one year. Surface water of Charleston Harbor was also analyzed to examine environmental distribution in an estuarine ecosystem. Of the 19 compounds examined, 11 were quantified in wastewater influent, 9 in effluent, and 7 in surface water. Aqueous concentrations of many PPCPs were reduced by $>86 \%$ in wastewater effluent compared with influent, though some compounds showed low removal and greater effluent concentrations compared with influent (e.g. estrone and fluoxetine). Differences in effluent concentrations and estimated removal between facilities were likely related to variations in the facilities' operating procedures. Surface water concentrations were generally reduced by $>90 \%$ for those chemicals found in effluent. Additionally, there were seasonal trends that indicate reduced degradation in colder months in wastewater and surface water. To our knowledge, this is the first study examining PPCPs in the South Atlantic Bight.
\end{abstract}

(c) 2012 Elsevier B.V. All rights reserved.

\section{Introduction}

The presence of pharmaceuticals and personal care products (PPCPs) and their metabolites in the environment has become a growing area of research in environmental science. PPCPs consist of

\footnotetext{
Abbreviations: WWTP, wastewater treatment plant; CWS, Charleston Water System; MPW, Mount Pleasant Waterworks; MRL, method reporting limit.

* Correspondence to: M.L. Hedgespeth, Aquatic Ecology, Department of Biology, Lund University, Sölvegatan 37, SE-223 62 Lund, Sweden. Tel.: + 4646 2223752; fax: + 46462224536 .

** Correspondence to: E. Wirth, Center for Human Health Risk, Hollings Marine Laboratory, NOAA, NOS, NCCOS, 331 Fort Johnson Rd., Charleston, SC 29412, USA E-mail addresses: Melanie.Hedgespeth@biol.lu.se (M.L. Hedgespeth), Ed.Wirth@noaa.gov (E. Wirth).

${ }^{1}$ Present Address: US Department of Agriculture, Agricultural Research Service, Eastern Regional Research Center, 600 East Mermaid Ln., Wyndmoor, PA, 19038, USA.
}

commonly used over-the-counter and prescription drugs and chemicals found in consumer products. The entry of PPCPs into the environment can result in inadvertent exposure of non-target organisms, resulting in a range of potential impacts. For example, widespread use of antimicrobial products and prescription antibiotics has been implicated in the selection for antibiotic-resistance in bacteria (Chee-Sanford et al., 2001). Bioaccumulation of antimicrobials, hormones, and antidepressants has been shown to occur in a variety of aquatic organisms (DeLorenzo et al., 2008; Fair et al., 2009; Gomes et al., 2004; Nakamura et al., 2008). Additionally, environmentally-relevant levels (e.g. $5 \mathrm{ng} / \mathrm{L}$ ) of the synthetic estrogen ethinylestradiol found in oral contraceptives have been shown to cause reproductive failure in fish (Nash et al., 2004) and the eventual collapse of a fish population (Kidd et al., 2007). 
PPCPs are introduced into aquatic environments by both pointand nonpoint-sources such as domestic wastewater treatment plant (WWTP) effluent, among others (Daughton and Ternes, 1999). One of the largest inputs into the environment results from the human ingestion and subsequent excretion of pharmaceuticals (Williams, 2005); up to $90 \%$ of a drug can be excreted in its original, active form (Halling-Sørensen et al., 1998). The nearly universal use of these types of products by consumers results in constant input into not only WWTPs, but also constant, low-level input into the environment itself.

Some PPCPs may be degraded during wastewater treatment whereas others may pass through the process largely unchanged, remaining dissolved and becoming diluted or sorbing to solids that settle out of the waste stream (Aga, 2008). For example, some compounds such as triclocarban demonstrate high removal from the aqueous phase of wastewater; however, it is fairly persistent in the solid phase (Heidler et al., 2006). Additionally, the impact of degradation products must also be considered as some transformed chemicals are potentially more mobile or persistent than their parent compounds (Aga, 2008). Some PPCP metabolites that have been conjugated into less biologically active forms within the consumer's body can become deconjugated into their active forms during wastewater treatment or in the environment due to microbial action (Huang and Sedlak, 2001; Ternes, 1998). Overall, the effectiveness of PPCP removal can be highly variable within and between facilities due to general operating conditions, technology used, microbial community composition, and methods of disinfection (Khanal et al., 2006; Radjenovic et al., 2009; Suarez et al., 2008). Because of this and the diversity of chemicals contained within the term "РPCP", relatively little can be inferred about removal and subsequent discharge of one chemical to another, as well as chemicals from one facility to another.

Because WWTPs serve as major point-sources of PPCPs in the environment, examining the flow and distribution from facilities into receiving environments may allow for a clearer assessment of whether sensitive ecosystems may be at risk. Estuaries are a critical link between freshwater and marine ecosystems - they serve as feeding, spawning, and nursery grounds for a variety of economically and biologically important organisms and are some of the most productive ecosystems on the planet (Odum, 1983). In order to minimize potential negative impacts of increasing urban development in coastal zones, monitoring these sensitive ecosystems is vital. Multiple studies have demonstrated the presence of low concentrations of PPCPs in freshwater environments that serve as discharge locations for treated WWTP effluent (Boyd et al., 2003; Kim et al., 2007; Ternes et al., 1999a); however, many works do not include discussion of PPCPs in coastal settings. Few studies to date have examined PPCPs in saline environments (Benotti and Brownawell, 2009; Pait et al., 2006; Singh et al., 2010).

The objective of this study was to assess the distribution and seasonal trends of 19 target PPCPs, including 11 hormones (Table 1), within WWTPs in Charleston, SC, USA, over the period of one year. Because these facilities discharge treated effluent into the Charleston Harbor, surface water of the harbor was analyzed to examine environmental distribution of PPCPs in an estuarine ecosystem of the South Atlantic Bight.

\section{Methods}

\subsection{Sample collection}

Wastewater was sampled from two local water utilities (Charleston Water System "CWS" and Mount Pleasant Waterworks "MPW") in Charleston County, SC, from April 2009 to March 2010. The CWS wastewater treatment plant has an average flow of 20 million gallons/day (MGD). It utilizes primary and secondary treatment methods and disinfects effluent with sodium hypochlorite (Andy Fairey, CWS, personal
Table 1

PPCPs analyzed in this study, their monitored m/z's (Q1: parent, $Q 3^{\mathrm{q}}$ : product used for quantification, $\mathrm{Q}^{\mathrm{c}}$ : product used for confirmation), and the MRL for wastewater (WW) and surface water (SW) samples.

\begin{tabular}{|c|c|c|c|}
\hline Analyte & Commercial use & $\mathrm{Q} 1 / \mathrm{Q3}^{\mathrm{q}}, \mathrm{Q}^{\mathrm{c}}$ & $\begin{array}{l}\text { MRL (ng/L): } \\
\text { WW/SW }\end{array}$ \\
\hline Acetaminophen & Analgesic/antipyretic & $152.1 / 93.1,110.1$ & $50.00 / 10.00$ \\
\hline Caffeine & Stimulant & $195.2 / 110.1,138.1$ & $25.00 / 5.00$ \\
\hline Cotinine & Metabolite of nicotine & $177.1 / 98.1,80.1$ & $18.75 / 3.75$ \\
\hline $\begin{array}{l}\text { Diethylstilbestrol } \\
\text { (DES) }\end{array}$ & $\begin{array}{l}\text { Synthetic nonsteroidal } \\
\text { estrogen }\end{array}$ & $267.0 / 237.0,222.0$ & $25.00 / 5.00$ \\
\hline Equilenin & $\begin{array}{l}\text { Steroid hormone } \\
\text { (estrogen) }\end{array}$ & $265.0 / 221.0,249.0$ & $12.50 / 2.50$ \\
\hline Equilin & $\begin{array}{l}\text { Steroid hormone } \\
\text { (estrogen) }\end{array}$ & 267.0/143.0, 223.0 & $12.50 / 2.50$ \\
\hline $17 \alpha$-Estradiol & $\begin{array}{l}\text { Steroid hormone } \\
\text { (estrogen) }\end{array}$ & $271.1 / 144.9,183.0$ & $12.50 / 2.50$ \\
\hline $17 \beta$-Estradiol (E2) & $\begin{array}{l}\text { Steroid hormone } \\
\text { (estrogen) }\end{array}$ & $271.1 / 144.9,183.0$ & $5.00 / 1.00$ \\
\hline Estriol (E3) & $\begin{array}{l}\text { Steroid hormone } \\
\text { (estrogen) }\end{array}$ & 287.0/171.0, 145.0 & $5.00 / 1.00$ \\
\hline Estrone (E1) & $\begin{array}{l}\text { Steroid hormone } \\
\text { (estrogen) }\end{array}$ & 269.0/145.0, 159.0 & $5.00 / 1.00$ \\
\hline $\begin{array}{l}17 \alpha \text {-Ethinylestradiol } \\
\quad(\mathrm{EE} 2)\end{array}$ & $\begin{array}{l}\text { Synthetic steroidal } \\
\text { estrogen }\end{array}$ & 295.0/145.0, 159.0 & $12.50 / 2.50$ \\
\hline Fluoxetine & Antidepressant & $310.1 / 44.2,148.2$ & $18.75 / 3.75$ \\
\hline Ibuprofen & NSAID & 205.0/158.9, 160.9 & $25.00 / 5.00$ \\
\hline Norfluoxetine & Metabolite of fluoxetine & 296.2/134.1, 30.2 & $18.75 / 3.75$ \\
\hline Norgestrel & Synthetic progestogen & $313.0 / 109.0,245.0$ & $5.00 / 1.00$ \\
\hline Progesterone & $\begin{array}{l}\text { Steroid hormone } \\
\text { (progestogen) }\end{array}$ & 315.0/109.0, 97.0 & $25.00 / 5.00$ \\
\hline Testosterone & $\begin{array}{l}\text { Steroid hormone } \\
\text { (androgen) }\end{array}$ & $289.0 / 97.0,109.0$ & $5.00 / 1.00$ \\
\hline Triclocarban & Antimicrobial & 312.9/126.0, 159.8 & $12.50 / 2.50$ \\
\hline Triclosan & Antimicrobial & 286.9/35.0, - & $50.00 / 10.00$ \\
\hline
\end{tabular}

communication). The MPW facility has an average flow of 5.1 MGD and treats wastewater similarly to CWS, but additionally utilizes an anoxic basin (Allan Clum, MPW, personal communication). Within each facility, 24-hour composite samples were collected monthly in influent and post-chlorination effluent streams.

Surface water samples were collected in the Charleston Harbor of Charleston, SC (Fig. 1), from each of the two wastewater outfall locations (Site 2: MPW, Site 5: CWS) and four additional sites in the harbor (Site 1: offshore entrance to harbor, Site 3: Cooper River-Wando River confluence, Site 4: central location, Site 6: Ashley River). Monthly samples were collected from approximately $2 \mathrm{~m}$ below the surface using a Niskin bottle during an outgoing tide within 12$48 \mathrm{~h}$ after wastewater samples were collected. All wastewater and surface water samples were held in glass bottles for transport on ice in the dark until receipt at the laboratory. All were extracted within $24 \mathrm{~h}$ of collection - those not extracted immediately were stored at $4{ }^{\circ} \mathrm{C}$ in the dark.

\subsection{Sample extraction}

Table 1 lists the target analytes examined in this study (these were chosen because they are products commonly used by consumers and/ or are compounds that have the potential to pose environmental risk to non-target organisms, based on the data from the available literature). Samples were extracted according to the published EPA Method 1694 (USEPA, 2007), with slight modification. Analytes fall into two categories identified in EPA 1694 - Group 1 (acetaminophen, caffeine, cotinine, fluoxetine, norfluoxetine) and Group 3 (ibuprofen, triclocarban, triclosan). Additionally, 11 natural and synthetic hormones were quantified in this study; EPA Method 1694 was modified to include these (Sapozhnikova et al., 2011). Thus, all target analytes were monitored in the final sample extracts. The eight estrogenic hormones were not monitored for the first month of the study due to unavailability of matched labeled surrogate standards, but were 
$79^{\circ} 55^{\prime} 0^{\prime \prime} \mathrm{W}$
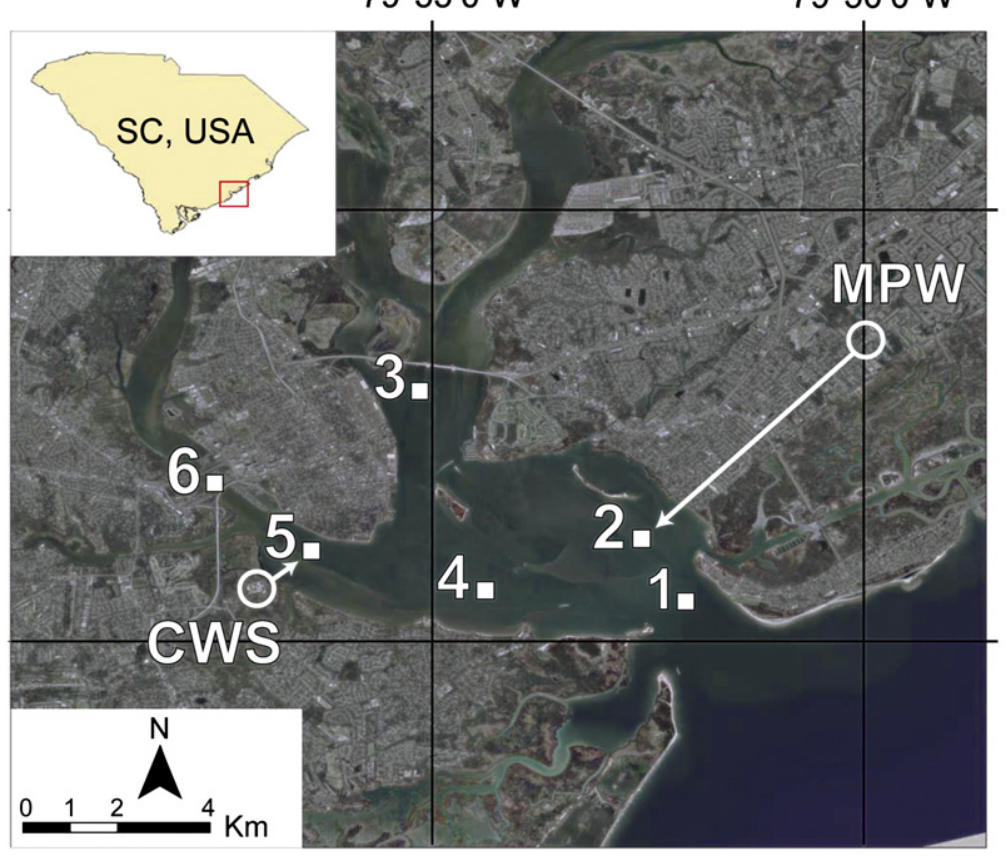

$79^{\circ} 50^{\prime} 0^{\prime \prime} \mathrm{W}$

\section{$-32^{\circ} 45^{\prime} 0^{\prime \prime} \mathrm{N}$}

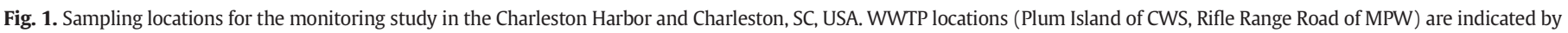
circles; surface water sample collection sites ( 6 total) are designated by squares. Surface water sample sites located at discharge locations for each WWTP are indicated by arrows.

subsequently monitored for the remaining 11 months. Method precision was initially verified using polished seawater and prepared synthetic effluent (Sapozhnikova et al., 2011).

Only PPCPs dissolved in the aqueous phase were measured in this study; therefore wastewater samples underwent vacuum filtration ( $1 \mu \mathrm{m}$ Whatman Glass Microfibre Filters). Initial method development indicated that volumes of $100 \mathrm{~mL}$ for influent and 200$250 \mathrm{~mL}$ for effluent were sufficient for use in SPE procedures. Samples were adjusted to $\mathrm{pH} 2.00 \pm 0.05$ using hydrochloric acid, spiked with matched labeled surrogate standards, stabilized with $\mathrm{Na}_{4}$ EDTA $\cdot 2 \mathrm{H}_{2} \mathrm{O}$, and underwent solid phase extraction (SPE) using Waters Oasis HLB $\left(1 \mathrm{~g}, 20 \mathrm{~cm}^{3} / 1 \mathrm{~g} \mathrm{LP}, 60 \mu \mathrm{m}\right)$ cartridges. Next, cartridges were dried for $30 \mathrm{~min}$, then analytes were eluted (according to EPA 1694) and extracts were evaporated to dryness. Methanol $(0.5 \mathrm{~mL})$ was used for reconstitution and extracts were filter centrifuged $(0.45 \mu \mathrm{m}$ nylon filter). After transfer to amber autosampler vials, HPLC water $(0.6 \mathrm{~mL})$ was added along with the labeled injection internal standards. Atrazine- $d_{5}$ was used as an injection internal standard for analysis of analytes in Group 1 as well as for norgestrel, progesterone, and testosterone. ${ }^{13} \mathrm{C}_{6}-2,4,5$-Trichlorophenoxyacetic acid was used as an injection internal standard for analytes in Group 3 and phenacetin (ethoxy-1-13C) served as an injection internal standard for the eight estrogenic hormones.

Surface water samples $(1 \mathrm{~L})$ underwent the same extraction procedures as wastewater, except $150 \mathrm{~mL}$ reservoir tubes containing $10 \mu \mathrm{m}$ polyethylene frits were attached to HLB cartridges during SPE loading for filtering particulate matter. A reagent blank using HPLC water, sample replicate, and matrix spike were extracted with each sample batch for quality assurance/quality control.

\subsection{Sample analysis}

An Agilent 1100 HPLC system (Agilent Technologies Inc.) coupled with an API-4000 triple quadrupole mass spectrometer (Applied Biosystems/MDS Sciex) was used with an Xterra MS C18 column (Waters Corp., $3.5 \mu \mathrm{m}, 2.1 \times 100 \mathrm{~mm}$ ) in a $40{ }^{\circ} \mathrm{C}$ column oven to separate analytes using a binary gradient (USEPA, 2007). Analytes were detected using a multiple reaction monitoring mode. The autosampler tray temperature was set at $4{ }^{\circ} \mathrm{C}$ for all samples. For analysis of Group $1(\mathrm{ESI}+)$ and Group 3 (ESI -) PPCPs, HPLC procedures followed steps outlined in EPA Method 1694; procedures for analysis of hormones are described in Sapozhnikova et al. (2011). Progesterone, testosterone, and norgestrel were added to the acquisition method for Group 1 analytes. The remaining estrogens were analyzed using a reverse phase Phenomenex Gemini-NX C18 column $(3 \mu \mathrm{m}, 50 \times 2.0 \mathrm{~mm}$ ) fitted with a guard column (Phenomenex Gemini-NX C18, $4 \times 2.0 \mathrm{~mm}$ ) at $30^{\circ} \mathrm{C}$.

Two parent-product transition mass-to-charge transitions $\left(\mathrm{m} / \mathrm{z}^{\prime} \mathrm{s}\right)$ were monitored for most analytes (Table 1 ) and ratios of product transitions were calculated to ensure correct identification. Calibration curves used for quantification (minimum of 5 levels) were linear for all compounds with $r^{2}>0.98$ for Group 1 and Group 3 analytes and $r^{2}>0.99$ for hormones. A continuous calibration verification sample was run every six samples within each monthly batch of samples.

\subsection{Statistical analyses}

Method reporting limits (MRLs; Table 1), were calculated according to Vanderford et al. (2003). Data were analyzed using R 2.10.1 and SAS 9.1 with $\alpha=0.05$ for all statistical tests. Assumptions of parametric analyses were tested using a Shapiro-Wilk test and Bartlett's test; appropriate transformations were applied if needed (as described in each of the following sections).

\subsubsection{Site differences}

Detection probabilities of analytes were calculated (PROC FREQ in SAS). A generalized linear model (logistic regression with a binomial distribution) was fit to the data by maximum likelihood estimation of parameters and using a logit link function in SAS in order to examine the probability of detects vs. nondetects. For wastewater samples, average annual concentrations for PPCPs detected above MRLs were compared using two sample $t$-tests. Data that did not meet the assumption of normality after logarithmic transformation were analyzed using an exact Wilcoxon Mann-Whitney rank sum test. (More information on statistical tests used for these analyses is described in Appendix A.) For surface water samples, only caffeine concentrations were examined due 
to its high detection frequency. Analysis of variance (ANOVA) of the $z$ score transformed data was used to determine if concentrations varied by site.

\subsubsection{Wastewater removal efficiencies}

Estimated percentages of analyte removal in the aqueous phase during wastewater treatment were calculated for both facilities as ([influent] - [effluent] $) \div$ [influent] $\times 100$. Non-detects in effluent samples were assumed to have a concentration at the MRL (vs. $0 \mathrm{ng} / \mathrm{L}$, for example) for each respective analyte, resulting in a conservative estimate of minimum removal percentage. To resolve whether statistical differences in removal existed between WWTPs, analysis of covariance (ANCOVA, Type III SS) was used to compare slopes of influent-effluent regressions for compounds where detection was $100 \%$ in both influent and effluent samples. Only those chemicals with $>60.0 \%$ detection in wastewater were individually analyzed after using Helsel's robust method for uncensoring data (Helsel, 1990, 2005) prior to the ANCOVA analyses. (Chemicals with lower detection frequency were not analyzed.)

\subsubsection{Seasonality}

Spring (March 2010, April and May 2009), summer (June, July, August 2009), fall (September, October, November 2009), and winter (December 2009, January and February 2010) sampling months were compared to examine seasonal trends in detection/concentration. Detection probabilities of analytes were calculated and statistically analyzed as described previously for site differences. Concentrations of PPCPs in wastewater were examined in relation to season using ANOVA with a Tukey HSD test for pairwise comparisons. WWTPs were examined separately; only compounds with $100 \%$ detection in influent and $>91.0 \%$ detection in effluent were analyzed. Logarithmic transformations were applied to the analyses of acetaminophen, caffeine, and cotinine in wastewater to meet the assumptions for parametric tests. Due to no/limited detection in surface water for PPCPs in some months, only the three most frequently detected compounds in surface waters (caffeine, cotinine, acetaminophen) were analyzed for seasonal trends.

\section{Results and discussion}

\subsection{Wastewater samples}

The ranges of PPCP concentrations detected in this study are comparable to concentrations reported in other studies (Agüera et al., 2003; Trenholm et al., 2006; Vanderford and Snyder, 2006; Zhou et al., 2010). Eleven of the target compounds were detected above MRLs in influent samples of both WWTPs (Table 2). For both facilities, acetaminophen, caffeine, and ibuprofen were detected in the first, second, and third largest concentrations, respectively. This is not surprising, given that these are found in numerous over-the-counter and prescription medications. Additionally, caffeine is present in a wide assortment of consumer items. The 1998-1999 Slone Survey reported acetaminophen as the first and ibuprofen as the second most commonly used drugs in American households. Caffeine ranked ninth based on OTC/prescription drug use only; food/beverage content was not considered (Kaufman et al., 2002).

In this study, triclosan and triclocarban were the fourth and fifth ranked PPCPs detected in wastewater based on influent concentrations. Both are antimicrobial compounds found in a variety of consumer products including soaps, toothpastes, etc. Although production volume numbers for triclosan in the USA are difficult to discern, widespread use and estimated production in the European Union (10-1000 t/year, Dye et al., 2007) indicate that the numbers are likely high in the USA as well. Triclocarban was reported as a Moderate Production Volume compound in 2005 with less than $500,000 \mathrm{lb}$ of import/production in the USA (USEPA, 2009). Cotinine, a human metabolite of nicotine, followed as the sixth highest PPCP detected in influent.

Nine compounds were detected above MRLs in effluent samples of CWS (Table 2). Eight of these were also detected in MPW effluent samples; estrone was not detected. Caffeine and ibuprofen ranked as the top two PPCPs detected, followed by triclocarban $>$ acetaminophen $>$ triclosan. Acetaminophen, triclosan, and triclocarban most likely differed in ranking between influent and effluent due to increased removal during treatment (Fig. 2). It has been noted in other studies that triclocarban is more persistent throughout wastewater treatment than triclosan (Heidler and Halden, 2007; Heidler et al., 2006).

Table 2

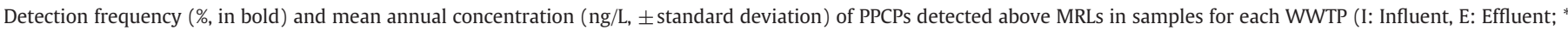
indicates significant differences between WWTPs), and surface water (na: not detected/unable to calculate).

\begin{tabular}{|c|c|c|c|c|}
\hline \multirow[t]{2}{*}{ Analyte } & \multicolumn{3}{|c|}{ WWTP } & \multirow[t]{2}{*}{ Surface water } \\
\hline & Site & CWS & MPW & \\
\hline \multirow[t]{2}{*}{ Acetaminophen } & I & (100) $99498 \pm 29368$ & (100) $113281 \pm 38596$ & (22.2) $15 \pm 5$ \\
\hline & $\mathrm{E}$ & (100) $354 \pm 752$ & (100) $152 \pm 87$ & \\
\hline \multirow[t]{2}{*}{ Caffeine } & $I^{*}$ & (100) $66400 \pm 15447$ & (100) $82882 \pm 16359$ & (98.6) $19 \pm 11$ \\
\hline & $E^{*}$ & (100) $924 \pm 865$ & (91.6) $207 \pm 498$ & \\
\hline \multirow[t]{2}{*}{ Cotinine } & I & (100) $1461 \pm 437$ & (100) $1598 \pm 363$ & (33.3) $6 \pm 2$ \\
\hline & $E^{*}$ & $(\mathbf{1 0 0}) 49 \pm 44$ & (100) $72 \pm 32$ & \\
\hline \multirow[t]{2}{*}{ Estriol } & $I^{*}$ & (100) $175 \pm 48$ & (100) $217 \pm 26$ & $(\mathbf{0})$ na \\
\hline & $\mathrm{E}$ & (0) na & (0) na & \\
\hline \multirow{2}{*}{ Estrone } & $I^{*}$ & (100) $31 \pm 7$ & (100) $40 \pm 12$ & $(\mathbf{0})$ na \\
\hline & $\mathrm{E}^{*}$ & $(81.8) 38 \pm 24$ & (0) na & \\
\hline \multirow[t]{2}{*}{ Fluoxetine } & I & (100) $61 \pm 22$ & (100) $75 \pm 24$ & $(\mathbf{0})$ na \\
\hline & $\mathrm{E}$ & (100) $60 \pm 17$ & (100) $56 \pm 24$ & \\
\hline \multirow[t]{2}{*}{ Ibuprofen } & I & (100) $24317 \pm 8797$ & (100) $24033 \pm 7713$ & (4.2) $8 \pm 3$ \\
\hline & $\mathrm{E}^{*}$ & $(66.7) 928 \pm 779$ & $(8.3) 2600 \pm$ na & \\
\hline \multirow[t]{2}{*}{ Norfluoxetine } & $I^{*}$ & $(\mathbf{1 0 0}) 45 \pm 13$ & (100) $58 \pm 15$ & (2.8) $7 \pm 3$ \\
\hline & $\mathrm{E}$ & (41.7) $20 \pm 1$ & (8.3) $26 \pm$ na & \\
\hline \multirow[t]{2}{*}{ Testosterone } & I & (100) $42 \pm 21$ & (100) $46 \pm 17$ & $(\mathbf{0})$ na \\
\hline & $\mathrm{E}$ & (0) na & (0) na & \\
\hline \multirow[t]{2}{*}{ Triclocarban } & $\mathrm{I}$ & $(\mathbf{1 0 0}) 4566 \pm 3520$ & (100) $4644 \pm 2369$ & (6.9) $3 \pm 1$ \\
\hline & $E^{*}$ & (100) $617 \pm 273$ & (100) $311 \pm 359$ & \\
\hline \multirow[t]{2}{*}{ Triclosan } & I & (100) $5341 \pm 2878$ & $(\mathbf{1 0 0}) 6817 \pm 3348$ & (6.9) $20 \pm 12$ \\
\hline & $\mathrm{E}$ & (75.0) $129 \pm 66$ & (33.3) $163 \pm 166$ & \\
\hline
\end{tabular}




\subsubsection{Site differences}

For influent, annual average concentrations of caffeine $(p=0.019)$, estriol ( $p=0.018)$, estrone $(p=0.048)$, and norfluoxetine $(p=0.022)$ were significantly higher in MPW compared with CWS (Table 2). For effluent, cotinine was detected in significantly higher concentrations in MPW vs. CWS $(p=0.025)$. Conversely, caffeine $(p=0.004)$, ibuprofen $(p=0.009)$, and triclocarban $(p=0.004)$ concentrations were significantly higher in CWS effluent, as well as estrone $(p<0.001$, due to no detection in MPW). Overall, the probability of detecting pooled target analytes in effluent was higher in CWS (70\%) vs. MPW (50\%, $X^{2}=$ $10.65, d f=1, p=0.001$; based on PROC FREQ analysis). In addition, the probability of detection was higher for effluent in CWS (81.8\%) vs. MPW (57.6\%) specifically for winter samples (seasonal trends further explained in the next section). Differences in detection and concentrations of PPCPs in effluent samples may be related to effluent composition (i.e. particulate matter), slight differences in the treatment process of MPW (anoxic basin) vs. CWS, microbial community composition in the WWTPs, and perhaps the size of the WWTPs.

\subsubsection{Removal efficiencies}

Overall, estimated percent removal of most compounds was high in both facilities (Fig. 2), and variable removal among individual compounds is most likely reflective of the variable nature of the chemicals' properties. Statistical analyses of acetaminophen, cotinine, fluoxetine, and triclocarban, and after uncensoring non-detect values in the data, caffeine, ibuprofen, norfluoxetine, and triclosan, indicated no significant difference in removal from CWS vs. MPW. Although effluent concentrations displayed significant differences between facilities for some of these compounds, these were highly variable. Thus, estimated removal did not statistically differ between plants.

Estrone was the only compound that demonstrated a significant difference in removal between facilities. After uncensoring non-detect values for estrone, removal in MPW was higher than CWS (Figs. 2, 3, $p=0.022$ ). It is possible that aqueous removal was higher for MPW vs. CWS because MPW's facility utilizes an anoxic basin as an additional step in the wastewater treatment process; both anoxic and anaerobic conditions have been shown to accelerate the removal of estrone, estradiol, and ethinylestradiol (Joss et al., 2004; Kreuzinger et al., 2004). A review by de Mes et al. (2005) suggests that removal of estrogens during denitrification in anoxic conditions is due largely to adsorption as opposed to conjugation. Thus, the additional treatment step in MPW may have allowed for additional solid sorption, resulting in lower concentrations in the aqueous phase. The solid fractions of wastewater samples were not examined in this study, although monitoring the concentrations of these compounds in both the aqueous and solid matrices, as well as at different steps of the treatment process, would more precisely reveal distribution of PPCPs in these WWTPs.

On almost half of the sampling dates, estrone concentrations in CWS effluent exceeded influent concentrations (as indicated by negative percentages for estimated removal in Fig. 2; see also Fig. 3 and Appendix B); high effluent concentrations vs. low influent concentrations may occur due to transformation and/or deconjugation during treatment. For example, $17 \beta$-estradiol can be broken down into estrone by bacteria present in activated sludge of WWTPs, bacteria in the surface waters, and via photolysis (Khanal et al., 2006).

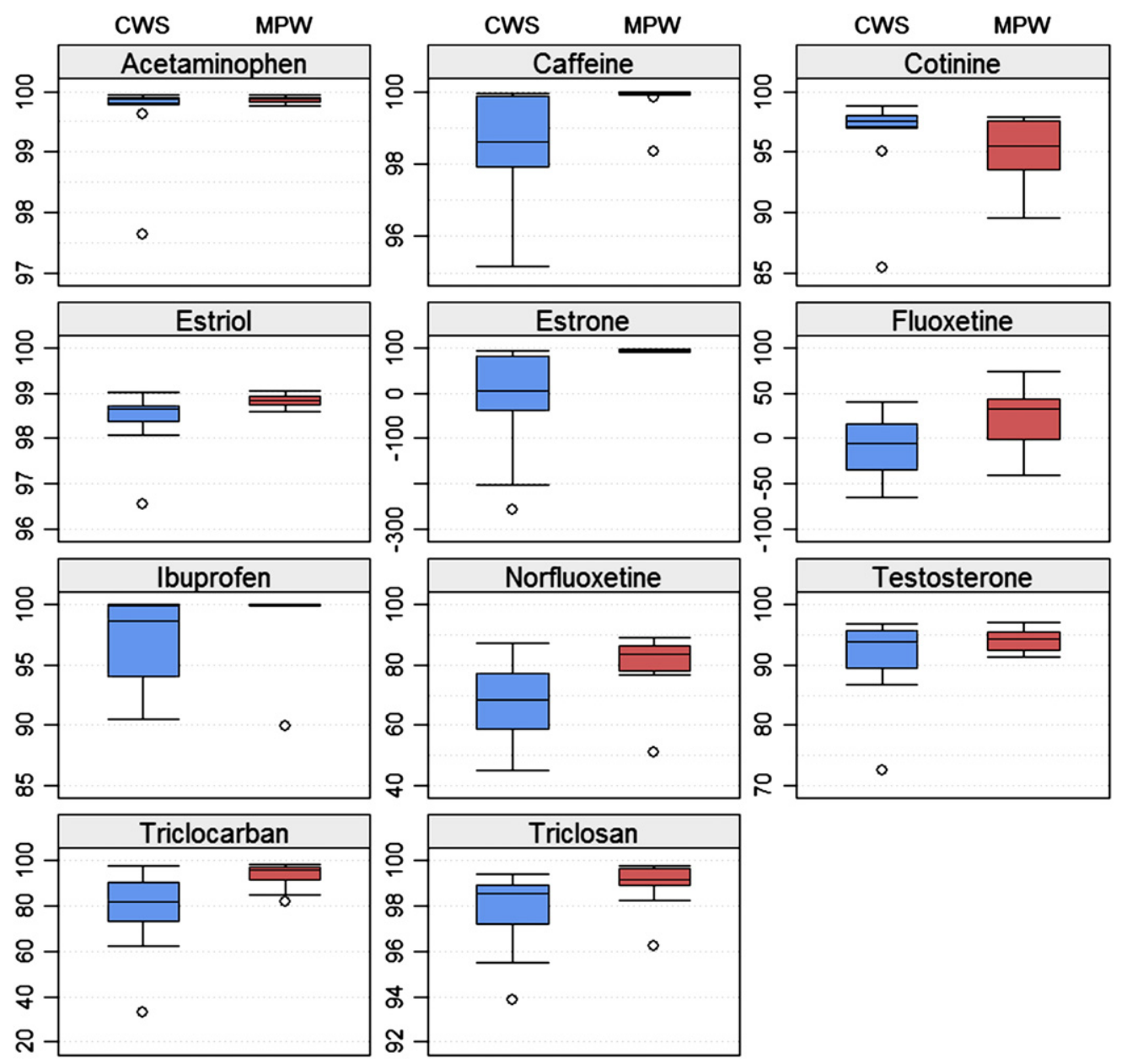

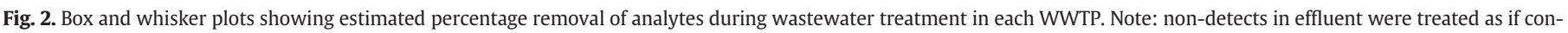
centrations were at MRL levels, resulting in a conservative, minimum estimate for removal. 


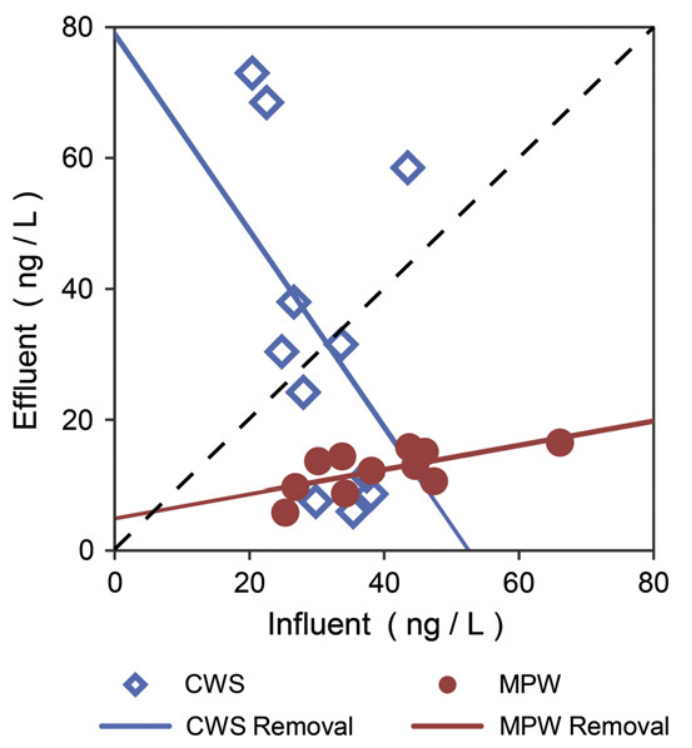

Fig. 3. Mean concentrations ( $\mathrm{ng} / \mathrm{L}$ ) of estrone in effluent compared with influent for CWS and MPW. Solid lines represent removal trends for each facility; the dashed line represents the theoretical trend line for $0 \%$ removal.

Biodegradation results in the removal of $17 \beta$-estradiol, but conversion of estrone into nonestrogenic products has been suggested as the rate-limiting step in estrogen biodegradation (Yu et al., 2006). In addition, estrone is largely excreted from the human body as estriol or in a conjugated form. It has been shown that there is potential for estrogen conjugates to be cleaved by microorganisms in wastewater sludge, resulting in an increase of the deconjugated form (Ternes et al., 1999b). This does not occur only with estrogens; conjugates of other organic compounds may also be cleaved resulting in higher effluent concentrations (Ternes, 1998). This may explain why larger concentrations of fluoxetine were also detected in effluent vs. influent on numerous sampling dates in both facilities (Fig. 2). After an oral dose in a healthy individual, it is estimated that $2.5 \%$ of the fluoxetine dose is excreted as the parent compound, $5.2 \%$ as the fluoxetine glucuronide conjugate, $10 \%$ as norfluoxetine, $9.5 \%$ as the norfluoxetine glucuronide conjugate, and the remainder as unidentified metabolites (Medscape and AHFS, 2010). Analysis of PPCPs including their conjugates would elucidate whether the deconjugation pathway in wastewater is responsible for increased effluent concentrations within local facilities.

\subsubsection{Seasonality}

Probability of detecting pooled PPCPs in effluent samples collected in winter was significantly higher in CWS (81.8\%) vs. MPW (57.6\%, $X^{2}=4.38, d f=1, p=0.036$; based on PROC FREQ analysis). No trends were apparent for other seasons when comparing CWS vs. MPW. Additionally there was a significantly higher probability of detection within CWS effluent for winter samples (81.8\%) compared with summer samples $\left(57.6 \%, X^{2}=4.38, d f=1, p=0.036\right)$ for pooled compounds. When analyzing frequency of detection for compounds on an individual basis, no significant seasonal trends were noted in influent or effluent; however, February 2010 was the only month where ibuprofen $(2600 \mathrm{ng} / \mathrm{L})$ and norfluoxetine $(26 \mathrm{ng} / \mathrm{L})$ were detected in MPW effluent (Appendix B). Acetaminophen, cotinine, and triclosan were detected in the highest concentrations for CWS effluent in February with estimated removal percentage being lowest for this month for acetaminophen (97.6\%) and cotinine (85.3\%) compared with other months (>99.6\%, $>94.9 \%$, respectively). Caffeine, triclocarban, and triclosan were detected in the highest concentrations for MPW effluent samples in February, which also corresponds to the lowest estimated removal percentage compared with all other months of the study (caffeine: $98.3 \%$ vs. $>99.8 \%$ other months; triclocarban: $82.0 \%$ vs. $>84.7 \%$; triclosan $96.2 \%$ vs. $>97.7 \%$ ). Totalized final effluent flow rates in the wastewater facilities in winter were higher than other seasons in both facilities; therefore, elevated detection does not appear to be caused by an increased concentration factor of the analytes in samples. Generally, high flow may have led to a shorter residence time of the sludge during the treatment process in winter, possibly resulting in lower removal of compounds. Corresponding influent concentrations were not elevated in February, suggesting that the relatively high effluent concentrations of these samples were perhaps a result of decreased removal during treatment and not increased input of PPCPs.

Reduced sunlight in winter months may have also resulted in reduced photodegradation; however, due to the high turbidity of wastewater and the depth of treatment tanks, photodegradation likely played a minimal role, if any. Upon examination of the wastewater quality data for winter, water temperature on the February sampling date was the lowest recorded for the study (CWS: $16.4{ }^{\circ} \mathrm{C}$, MPW: $16.6{ }^{\circ} \mathrm{C}$; maximum temperatures were $\sim 28^{\circ} \mathrm{C}$ in summer). Additionally, the total suspended solids and measured oxygen demands of both facilities' effluents were highest for the February sampling date compared with other months, indicating that lower temperatures in February likely reduced microbial activity of the activated sludge process, thus reducing biodegradation of the aforementioned compounds during treatment. Vieno et al. (2005) found a similar trend where increased concentrations of PPCPs in WWTP effluent correlated with the coldest month of the year; increased effluent concentrations were attributed to low temperatures reducing biodegradation during the treatment process.

Based on concentration, six PPCPs showed seasonal trends in influent and two demonstrated trends in effluent (Table 3). Estriol and estrone did not demonstrate significant differences by season in CWS influent, but did in MPW influent where concentrations were higher in the summer compared with spring and winter samples. Effluent concentrations could not be statistically analyzed for these compounds due to low detection frequency.

\subsection{Surface water samples}

Only seven PPCPs were detected in local surface waters (Table 2), with caffeine, cotinine, and acetaminophen being detected the most frequently $(98.6 \%, 33.3 \%, 22.2 \%$, respectively). This is in agreement with a nationwide USGS study (Kolpin et al., 2002), which detected these three compounds in the highest frequencies of its target analyte list as well $(61.9 \%, 38.1 \%, 23.8 \%$, respectively). This is not surprising, given the near universal use of these chemicals (or in the case of cotinine, its parent compound). The three chemicals were also detected in all influent samples in high concentrations and in almost every effluent sample with mean concentrations of caffeine $>$ acetaminophen $>$ cotinine (Table 2). Surface water mean and median concentrations also demonstrated caffeine $>$ acetaminophen $>$ cotinine (Table 2 ), which may be a reflection of WWTP effluent most likely being a major point-source input of these compounds into local surface waters, although these concentrations were generally reduced by $>90 \%$ compared to effluent concentrations.

The majority of studies on PPCPs in surface waters have examined freshwater environments; however, only a few studies have examined distribution of these compounds in marine or estuarine locations (Benotti and Brownawell, 2007; Pait et al., 2006; Singh et al., 2010). Concentrations of compounds detected in the Charleston Harbor are largely within/below those reported in other studies examining fresh and coastal waters (Kolpin et al., 2002; Pait et al., 2006; Vethaak et al., 2002). Interestingly, some compounds such as fluoxetine were not detected above MRLs in surface waters in this study, though they have been reported in multiple investigations examining PPCPs in other regions of the USA. Additionally, we detected norfluoxetine in two surface water samples (Site 1: 9 ng/L and Site 6: 4 ng/L, October 2009, Appendix B). Norfluoxetine has been detected in small, effluent-dominated 
Table 3

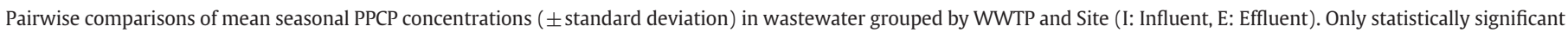
comparisons are shown.

\begin{tabular}{|c|c|c|c|c|c|c|c|}
\hline \multirow[t]{2}{*}{ Analyte } & \multirow[t]{2}{*}{ WWTP } & \multirow[t]{2}{*}{ Site } & \multicolumn{4}{|c|}{ Mean concentration (ng/L) } & \multirow[t]{2}{*}{$p$-value } \\
\hline & & & Spring & Summer & Fall & Winter & \\
\hline \multirow[t]{3}{*}{ Acetaminophen } & CWS & $\mathrm{I}$ & & $62973 \pm 7673$ & $133667 \pm 11060$ & & 0.003 \\
\hline & & & $104085 \pm 10762$ & $62973 \pm 7673$ & & & 0.028 \\
\hline & MPW & I & & $69423 \pm 9705$ & & $143000 \pm 26514$ & 0.031 \\
\hline \multirow[t]{4}{*}{ Caffeine } & CWS & I & & $48199 \pm 3976$ & $79967 \pm 5208$ & & 0.028 \\
\hline & & $\mathrm{E}$ & & $331 \pm 368$ & $1868 \pm 402$ & & 0.038 \\
\hline & & & $81 \pm 33$ & & $1868 \pm 402$ & & 0.007 \\
\hline & & & $81 \pm 33$ & & & $1417 \pm 723$ & 0.014 \\
\hline \multirow[t]{5}{*}{ Cotinine } & CWS & $\mathrm{I}$ & & $1234 \pm 258$ & $2051 \pm 53$ & & 0.023 \\
\hline & & & & & $2051 \pm 53$ & $1046 \pm 117$ & 0.005 \\
\hline & MPW & I & $1397 \pm 124$ & & $2131 \pm 271$ & & 0.005 \\
\hline & & & & $1337 \pm 71$ & $2131 \pm 271$ & & 0.003 \\
\hline & & & & & $2131 \pm 271$ & $1526 \pm 181$ & 0.017 \\
\hline \multirow[t]{2}{*}{ Estriol } & MPW & I & $191 \pm 4$ & $243 \pm 20$ & & & 0.032 \\
\hline & & & & $243 \pm 20$ & & $196 \pm 15$ & 0.031 \\
\hline \multirow[t]{2}{*}{ Estrone } & MPW & I & $28 \pm 3$ & $52 \pm 12$ & & & 0.038 \\
\hline & & & & $52 \pm 12$ & & $32 \pm 4$ & 0.050 \\
\hline \multirow[t]{4}{*}{ Fluoxetine } & CWS & I & & $33 \pm 8$ & $81 \pm 12$ & & 0.016 \\
\hline & & $E$ & $53 \pm 6$ & & $82 \pm 7$ & & 0.014 \\
\hline & & & & $43 \pm 4$ & $82 \pm 7$ & & 0.002 \\
\hline & MPW & I & $55 \pm 14$ & & $101 \pm 10$ & & 0.045 \\
\hline
\end{tabular}

streams from $1.3 \mathrm{ng} / \mathrm{L} \pm 25 \% \mathrm{RSD}$ (Vanderford and Snyder, 2006) to $13.6 \mathrm{ng} / \mathrm{L}$ (Schultz et al., 2010). Only rarely has norfluoxetine been reported in surface waters that are not effluent-dominated, and if so, in low concentrations: $2.88 \mathrm{ng} / \mathrm{L}$ (Conley et al., 2008). Further investigation into whether abiotic and/or biotic degradation of fluoxetine may be occurring in local surface waters is warranted because, 1.) there was a lack of detection of fluoxetine above MRL and limited detection of norfluoxetine in surface waters, and 2.) there were larger overall concentrations of fluoxetine compared with norfluoxetine detected in effluent (Table 2).

\subsubsection{Site differences}

When comparing sites in the Charleston Harbor (Fig. 1), there was a larger overall probability of detecting PPCPs (pooled compounds) at Site 6 (34.5\%) compared with Site $4(19.1 \%, p=0.025)$. When examining compounds individually, cotinine revealed significantly higher probability of detection at Site 6 (58.3\%) compared with Site 5 (16. $7 \%, p=0.045$ ), though the cause for this is unclear (Table 4). No other analytes detected in surface waters demonstrated statistically significant higher detection frequencies at Site 6 vs. other sites upon individual examination (Table 4).

Caffeine was the only compound for which concentrations were analyzed by site in surface water due to its high detection frequency. Concentrations were significantly higher at Site 6 compared with Sites 4 and 2 (Table 4). Concentrations were also significantly higher at Site 5 compared with Site 2 (both WWTP discharge sites in Charleston Harbor). This latter result agrees with wastewater samples: caffeine was detected in significantly higher concentrations in CWS effluent vs. MPW effluent.

One potential factor of increased detection of cotinine and larger concentrations of caffeine at Site 6 is that the Sites 3 and 6 are located at river inputs into the Charleston Harbor. Upstream locations along the rivers are developed, thus those sites may be impacted by upstream point and nonpoint-sources of PPCPs. However, the few site differences overall reflect the fact that the Charleston Harbor is a partially-mixed estuarine system, likely due to the large tidal flow within the region (Althausen and Kjerfve, 1992).

\subsubsection{Seasonality}

Only acetaminophen demonstrated significant seasonal trends in surface water. Its probability of detection in winter samples (55.6\%) was significantly higher than all other seasons: spring $(11.1 \%, p=$ 0.010 ), summer (16. 7\%, $p=0.020$ ), and fall (5. $6 \%, p=0.007)$. When comparing acetaminophen concentrations by season, there were no significant relationships. In WWTP effluent, concentrations of acetaminophen were not significantly related to season; thus, higher frequency of detection in winter surface water samples appears to be unrelated to wastewater concentrations. However, as stated previously, all compounds (pooled) were more frequently detected in CWS effluent in winter samples compared with summer samples. In addition, two of the three detections of ibuprofen above MRL in surface waters occurred in February 2010 (Appendix B), which is interesting given that the only detection of ibuprofen in MPW effluent also occurred in this same month. A study examining beta-blockers and antiepileptic compounds in WWTPs and surface waters found that mass flow loadings of compounds downstream of the WWTPs were highest in winter (Daneshvar et al., 2010). Researchers also found that the highest loss of compounds in surface waters coincided with the highest surface water temperatures and chlorophyll $a$ mass flows. The seasonal trend of increased detection in surface water in this study may be linked to increased detection in winter wastewater effluent samples. Skadsen et al. (2004) also found that PPCP concentrations in surface waters were highest in February samples compared with other months, resulting from high effluent concentrations in winter. Cold temperatures likely act upon wastewater and surface waters in a similar fashion, i.e. less light and colder temperatures in winter months could reduce photodegradation, depress bacterial and planktonic activity, and thus, alter biodegradation of compounds.

\section{Conclusions}

This study establishes a baseline of the presence, quantity, and spatial/ temporal distribution of PPCPs in wastewater and coastal surface waters of the South Atlantic Bight. Acetaminophen, caffeine, and ibuprofen were the three PPCPs detected most often in influent and effluent of both wastewater facilities based on concentration, whereas caffeine, cotinine, and acetaminophen were most frequently detected in surface water. Low estimated removal percentage and larger effluent concentrations of estrone and fluoxetine in comparison to influent may have been a result of deconjugation by bacteria in wastewater sludge, though further examination is warranted. Because our study only examined the aqueous phase of wastewater, we cannot infer whether removal in wastewater occurred via degradation of PPCPs or via sorption to particulate matter. However, because effluent samples contained very little, if any, filtered 
Table 4

Frequency/average annual concentration of all analytes detected above MRLs in Charleston Harbor surface water samples (see Fig. 1 for site locations). Overall surface water mean ("mean", \pm standard deviation) and median ("med") concentrations are also listed.

\begin{tabular}{|c|c|c|c|c|}
\hline $\begin{array}{l}\text { Analyte } \\
\text { mean } \pm \mathrm{sd}(\mathrm{ng} / \mathrm{L}) \\
\text { med }(\mathrm{ng} / \mathrm{L})\end{array}$ & Site & $\begin{array}{l}\text { Frequency of } \\
\text { detection } \\
(\%)\end{array}$ & $\begin{array}{l}\text { Mean } \\
\text { concentration } \\
(\mathrm{ng} / \mathrm{L})\end{array}$ & $\begin{array}{l}\text { Standard } \\
\text { deviation } \\
(\mathrm{ng} / \mathrm{L})\end{array}$ \\
\hline \multirow{6}{*}{$\begin{array}{l}\text { Acetaminophen } \\
\text { mean: } 12.9 \pm 6.52 \\
\text { med: } 12.3\end{array}$} & 1 & 16.7 & 18.0 & 7.14 \\
\hline & 2 & 25.0 & 11.8 & 1.52 \\
\hline & 3 & 8.3 & 10.2 & - \\
\hline & 4 & 8.3 & 10.4 & - \\
\hline & 5 & 33.3 & 10.9 & 6.55 \\
\hline & 6 & 41.7 & 14.2 & 9.51 \\
\hline \multirow{6}{*}{$\begin{array}{l}\text { Caffeine } \\
\text { mean: } 18.6 \pm 10.7 \\
\text { med: } 16.6\end{array}$} & 1 & 91.7 & 18.6 & 7.82 \\
\hline & 2 & 100 & 13.7 & 7.14 \\
\hline & 3 & 100 & 17.3 & 4.15 \\
\hline & 4 & 100 & 13.3 & 4.95 \\
\hline & 5 & 100 & 22.3 & 13.3 \\
\hline & 6 & 100 & 26.5 & 16.2 \\
\hline \multirow{6}{*}{$\begin{array}{l}\text { Cotinine } \\
\text { mean: } 5.71 \pm 2.27 \\
\text { med: } 4.91\end{array}$} & 1 & 41.7 & 4.84 & 0.98 \\
\hline & 2 & 25.0 & 7.58 & 5.92 \\
\hline & 3 & 33.3 & 6.12 & 2.08 \\
\hline & 4 & 25.0 & 5.55 & 0.89 \\
\hline & 5 & 16.7 & 5.70 & 1.99 \\
\hline & 6 & 58.3 & 5.39 & 1.33 \\
\hline \multirow{6}{*}{$\begin{array}{l}\text { Ibuprofen } \\
\text { mean: } 8.41 \pm 2.97 \\
\text { med: } 7.60\end{array}$} & 1 & 0 & - & - \\
\hline & 2 & 0 & - & - \\
\hline & 3 & 8.3 & 11.7 & - \\
\hline & 4 & 0 & - & - \\
\hline & 5 & 8.3 & 5.93 & - \\
\hline & 6 & 8.3 & 7.60 & - \\
\hline \multirow{6}{*}{$\begin{array}{l}\text { Norfluoxetine } \\
\text { mean: } 6.59 \pm 3.15 \\
\text { med: } 6.59\end{array}$} & 1 & 8.3 & 8.81 & - \\
\hline & 2 & 0 & - & - \\
\hline & 3 & 0 & - & - \\
\hline & 4 & 0 & - & - \\
\hline & 5 & 0 & - & - \\
\hline & 6 & 8.3 & 4.36 & - \\
\hline \multirow{6}{*}{$\begin{array}{l}\text { Triclocarban } \\
\text { mean: } 3.40 \pm 0.62 \\
\text { med: } 3.19\end{array}$} & 1 & 16.7 & 3.74 & 0.78 \\
\hline & 2 & 0 & - & - \\
\hline & 3 & 0 & - & - \\
\hline & 4 & 0 & - & - \\
\hline & 5 & 8.3 & 3.76 & - \\
\hline & 6 & 16.7 & 2.88 & 0.06 \\
\hline \multirow{6}{*}{$\begin{array}{l}\text { Triclosan } \\
\text { mean: } 19.6 \pm 12.1 \\
\text { med: } 12.6\end{array}$} & 1 & 16.7 & 12.3 & 0.36 \\
\hline & 2 & 16.7 & 16.8 & 8.29 \\
\hline & 3 & 0 & - & - \\
\hline & 4 & 0 & - & - \\
\hline & 5 & 0 & - & - \\
\hline & 6 & 8.3 & 39.4 & - \\
\hline
\end{tabular}

particulate matter, we believe that our study accurately depicts the transport of PPCPs from effluent into local surface waters. Overall, varying parameters that alter physical properties of the waste stream (i.e. $\mathrm{pH}$, suspended solids, etc.), as well as the use of additional treatment steps such as an anoxic basin, are likely to increase PPCP removal during domestic wastewater treatment.

Some of the highest PPCP concentrations in effluent samples were quantified on the coldest sampling date, indicating that lower temperatures may have reduced treatment efficiency. Additionally, acetaminophen was detected at a higher frequency in winter surface water samples, perhaps due to inhibition of abiotic/biotic degradation. Therefore, analyses of contaminants that include seasonal trends may indicate at what periods sensitive ecosystems may be at greater risk for exposure.

Additional research into the fate of PPCPs in coastal environments may shed light on how properties specific to these environments may play a role in future risk assessment. Not only dilution and tidal mixing, but also differences in physical properties (salinity, $\mathrm{pH}$, etc.) must be taken into account when examining coastal vs. freshwater recipients. The present study indicates that WWTP effluent is most likely a (if not the) major point-source input of PPCPs into Charleston Harbor. However, local surface waters appear to be relatively well-mixed due to the large tidal flow and measured environmental concentrations of PPCPs in this study indicate that there may be little to no risk for acute toxicity to non-target organisms (reviewed in Farré et al., 2008), though further examination into low-level, chronic exposure is warranted. In conclusion, it is important to consider the type of recipient environment and temporal variation of environmental conditions and inputs, along with potential impacts on organisms, to more accurately assess potential risks of anthropogenic substances. This will allow for a more responsible approach for the planning and management of urbanization in our coastal regions.

Supplementary data to this article can be found online at http:// dx.doi.org/10.1016/j.scitotenv.2012.07.076.

\section{Acknowledgments}

The authors thank the South Carolina Sea Grant Consortium, Charleston Water System, Mount Pleasant Water Works, College of Charleston, and NOAA for providing financial support for this project. Special thanks are given to Patty Iler, Blaine West, and James Daugomah. The National Ocean Service (NOS) does not approve, recommend, or endorse any proprietary product or material mentioned in this publication. Certain commercial equipment, instruments, or materials are identified in this paper to specify adequately the experimental procedure. Such identification does not imply recommendation or endorsement, nor does it imply that the materials or equipment identified are necessarily the best available for the purpose.

\section{References}

Aga DS. Fate of pharmaceuticals in the environment and in water treatment systems. Boca Raton: CRC Press; 2008.

Agüera A, Fernández-Alba AR, Piedra L, Mézcua M, Gómez MJ. Evaluation of triclosan and biphenylol in marine sediments and urban wastewaters by pressurized liquid extraction and solid phase extraction followed by gas chromatography mass spectrometry and liquid chromatography mass spectrometry. Anal Chim Acta 2003;480(2):193-205.

Althausen Jr JD, Kjerfve B. Distribution of suspended sediment in a partially mixed estuary, Charleston Harbor, South Carolina, U.S.A. Estuar Coast Shelf Sci 1992;35(5): 517-31.

Benotti MJ, Brownawell BJ. Distributions of pharmaceuticals in an urban estuary during both dry- and wet-weather conditions. Environ Sci Technol 2007;41(16):5795-802.

Benotti MJ, Brownawell BJ. Microbial degradation of pharmaceuticals in estuarine and coastal seawater. Environ Pollut 2009;157(3):994-1002.

Boyd GR, Reemtsma H, Grimm DA, Mitra S. Pharmaceuticals and personal care products (PPCPs) in surface and treated waters of Louisiana, USA and Ontario, Canada. Sci Total Environ 2003;311(1-3):135-49.

Chee-Sanford JC, Aminov RI, Krapac IJ, Garrigues-Jeanjean N, Mackie RI. Occurrence and diversity of tetracycline resistance genes in lagoons and groundwater underlying two swine production facilities. Appl Environ Microb 2001;67(4):1494-502.

Conley JM, Symes SJ, Schorr MS, Richards SM. Spatial and temporal analysis of pharmaceutical concentrations in the upper Tennessee River basin. Chemosphere 2008;73(8): 1178-87.

Daneshvar A, Svanfelt J, Kronberg L, Prévost M, Weyhenmeyer GA. Seasonal variations in the occurrence and fate of basic and neutral pharmaceuticals in a Swedish river-lake system. Chemosphere 2010;80(3):301-9.

Daughton CG, Ternes TA. Pharmaceuticals and personal care products in the environment: agents of subtle change? Environ Health Perspect 1999;107:907-38.

de Mes T, Zeeman G, Lettinga G. Occurrence and fate of estrone, 17ß-estradiol and $17 \alpha$-ethynylestradiol in STPs for domestic wastewater. Rev Environ Sci Biotechnol 2005;4(4):275-311.

DeLorenzo ME, Keller JM, Arthur CD, Finnegan MC, Harper HE, Winder VL, et al. Toxicity of the antimicrobial compound triclosan and formation of the metabolite methyltriclosan in estuarine systems. Environ Toxicol 2008;23(2):224-32.

Dye C, Schlabach M, Green J, Remberger M, Kaj L, Palm-Cousins A, et al. Bronopol, resorcinol, $\mathrm{m}$-cresol and triclosan in the Nordic environment. Copenhagen: Nordic Council of Ministers; 2007.

Fair PA, Lee H-B, Adams J, Darling C, Pacepavicius G, Alaee M, et al. Occurrence of triclosan in plasma of wild Atlantic bottlenose dolphins (Tursiops truncatus) and in their environment. Environ Pollut 2009;157(8-9):2248-54.

Farré Ml, Pérez S, Kantiani L, Barceló D. Fate and toxicity of emerging pollutants, their metabolites and transformation products in the aquatic environment. TrAC Trend Anal Chem 2008;27(11):991-1007.

Gomes RL, Deacon HE, Lai KM, Birkett JW, Scrimshaw MD, Lester JN. An assessment of the bioaccumulation of estrone in Daphnia magna. Environ Toxicol Chem 2004;23(1): $105-8$.

Halling-Sørensen B, Nors Nielsen S, Lanzky PF, Ingerslev F, Holten Lützhøft HC, Jørgensen SE. Occurrence, fate and effects of pharmaceutical substances in the environment - a review. Chemosphere 1998;36(2):357-93. 
Heidler J, Halden RU. Mass balance assessment of triclosan removal during conventional sewage treatment. Chemosphere 2007;66(2):362-9.

Heidler J, Sapkota A, Halden RU. Partitioning, persistence, and accumulation in digested sludge of the topical antiseptic triclocarban during wastewater treatment. Environ Sci Technol 2006;40(11):3634-9.

Helsel DR. Less than obvious - statistical treatment of data below the detection limit. Environ Sci Technol 1990;24(12):1766-74.

Helsel DR. Nondetects and data analysis: statistics for censored environmental data. Hoboken, NJ: John Wiley and Sons; 2005.

Huang $\mathrm{CH}$, Sedlak DL. Analysis of estrogenic hormones in municipal wastewater effluent and surface water using enzyme-linked immunosorbent assay and gas chromatography/tandem mass spectrometry. Environ Toxicol Chem 2001;20(1): 133-9.

Joss A, Andersen H, Ternes T, Richle PR, Siegrist H. Removal of estrogens in municipal wastewater treatment under aerobic and anaerobic conditions: consequences for plant optimization. Environ Sci Technol 2004;38(11):3047-55.

Kaufman DW, Kelly JP, Rosenberg L, Anderson TE, Mitchell AA. Recent patterns of medication use in the ambulatory adult population of the united states: the slone survey. J Am Med Assoc 2002;287(3):337-44.

Khanal SK, Xie B, Thompson ML, Sung S, Ong S-K, van Leeuwen J. Fate, transport, and biodegradation of natural estrogens in the environment and engineered systems. Environ Sci Technol 2006;40(21):6537-46.

Kidd KA, Blanchfield PJ, Mills KH, Palace VP, Evans RE, Lazorchak JM, et al. Collapse of a fish population after exposure to a synthetic estrogen. Proc Natl Acad Sci 2007;104(21): 8897-901.

Kim SD, Cho J, Kim IS, Vanderford BJ, Snyder SA. Occurrence and removal of pharmaceuticals and endocrine disruptors in South Korean surface, drinking, and waste waters. Water Res 2007;41(5):1013-21.

Kolpin DW, Furlong ET, Meyer MT, Thurman EM, Zaugg SD, Barber LB, et al. Pharmaceuticals, hormones, and other organic wastewater contaminants in U.S. streams, 1999-2000: a national reconnaissance. Environ Sci Technol 2002;36(6):1202-11.

Kreuzinger N, Clara M, Strenn B, Kroiss H. Relevance of the sludge retention time (SRT) as design criteria for wastewater treatment plants for the removal of endocrine disruptors and pharmaceuticals from wastewater. Water Sci Technol 2004;50(5):149-56.

Medscape, AHFS. Monograph-fluoxetine hydrochloride. November 2010. American Society of Health-System Pharmacists, Inc.; 2010. http://www.medscape.com/druginfo/ monograph?cid $=$ med\&drugid $=1774$.

Nakamura Y, Yamamoto H, Sekizawa J, Kondo T, Hirai N, Tatarazako N. The effects of pH on fluoxetine in Japanese medaka (Oryzias latipes): acute toxicity in fish larvae and bioaccumulation in juvenile fish. Chemosphere 2008;70(5):865-73.

Nash JP, Kime DE, Van der Ven LTM, Wester PW, Brion F, Maack G, et al. Long-term exposure to environmental concentrations of the pharmaceutical ethynylestradiol causes reproductive failure in fish. Environ Health Perspect 2004;112(17):1725-33.

Odum EP. Basic ecology. Philadelphia, PA: CBS College Publishing; 1983.

Pait AS, Warner RA, Hartwell SI, Nelson JO, Pacheco PA, Mason AL. Human use pharmaceuticals in the estuarine environment: a survey of the Chesapeake Bay, Biscayne Bay and Gulf of the Farallones. Silver Spring, MD: NOAA/NOS/NCCOS/Center for Coastal Monitoring and Assessment; 2006.

Radjenovic J, Petrovic M, Barceló D. Fate and distribution of pharmaceuticals in wastewater and sewage sludge of the conventional activated sludge (CAS) and advanced membrane bioreactor (MBR) treatment. Water Res 2009;43(3):831-41.

Sapozhnikova Y, Hedgespeth M, Wirth E, Fulton M. Analysis of selected natural and synthetic hormones by LC-MS-MS using the US EPA Method 1694. Anal Methods 2011;3(5):1079-86.
Schultz MM, Furlong ET, Kolpin DW, Werner SL, Schoenfuss HL, Barber LB, et al. Antidepressant pharmaceuticals in two U.S. effluent-impacted streams: occurrence and fate in water and sediment, and selective uptake in fish neural tissue. Environ Sci Technol 2010;44(6):1918-25.

Singh S, Azua A, Chaudhary A, Khan S, Willett K, Gardinali P. Occurrence and distribution of steroids, hormones and selected pharmaceuticals in South Florida coastal environments. Ecotoxicology 2010;19(2):338-50.

Skadsen JM, Rice BL, Meyering DJ. The occurrence and fate of pharmaceuticals, personal care products and endocrine disrupting compounds in a municipal water use cycle: a case study in the city of Ann Arbor. Ann Arbor, MI: City of Ann Arbor Water Utilities, Fleis \& VandenBrink Engineering, Inc.; 2004

Suarez S, Carballa M, Omil F, Lema JM. How are pharmaceutical and personal care products (PPCPs) removed from urban wastewaters? Rev Environ Sci Biotechnol 2008;7(2):125-38.

Ternes TA. Occurrence of drugs in German sewage treatment plants and rivers. Water Res 1998;32(11):3245-60.

Ternes TA, Kreckel P, Mueller J. Behaviour and occurrence of estrogens in municipal sewage treatment plants - II. Aerobic batch experiments with activated sludge. Sci Total Environ 1999a;225(1-2):91-9.

Ternes TA, Stumpf M, Mueller J, Haberer K, Wilken RD, Servos M. Behavior and occurrence of estrogens in municipal sewage treatment plants $-I$. Investigations in Germany, Canada and Brazil. Sci Total Environ 1999b;225(1-2):81-90.

Trenholm RA, Vanderford BJ, Holady JC, Rexing DJ, Snyder SA. Broad range analysis of endocrine disruptors and pharmaceuticals using gas chromatography and liquid chromatography tandem mass spectrometry. Chemosphere 2006;65(11):1990-8.

USEPA. Method 1694: pharmaceuticals and personal care products in water, soil, sediment, and biosolids by HPLC/MS/MS. Washington, DC: United States Environmental Protection Agency Office of Water; 2007. EPA 821-R-08-002.

USEPA. Initial risk-based prioritization of high production volume (HPV) chemicals: triclocarban. Washington, DC: United States Environmental Protection Agency; 2009.

Vanderford BJ, Snyder SA. Analysis of pharmaceuticals in water by isotope dilution liquid chromatography/tandem mass spectrometry. Environ Sci Technol 2006;40(23): 7312-20.

Vanderford BJ, Pearson RA, Rexing DJ, Snyder SA. Analysis of endocrine disruptors, pharmaceuticals, and personal care products in water using liquid chromatography/tandem mass spectrometry. Anal Chem 2003;75(22):6265-74.

Vethaak AD, Rijs GBJ, Schrap SM, Ruiter H, Gerritsen A, Lahr J. Estrogens and xenoestrogens in the aquatic environment of the Netherlands: occurrence, potency and biological effects. the Netherlands: Dutch National Institute of Inland Water Management and Waste Water Treatment (RIZA), Dutch National Institute for Coastal and Marine Management (RIKZ); 2002.

Vieno NM, Tuhkanen T, Kronberg L. Seasonal variation in the occurrence of pharmaceuticals in effluents from a sewage treatment plant and in the recipient water. Environ Sci Technol 2005;39(21):8220-6.

Williams RT, editor. Human pharmaceuticals: assessing the impacts on aquatic ecosystems. Pensacola, FL: SETAC Press; 2005.

Yu CP, Roh H, Chu KH. 17ß-Estradiol-degrading bacteria isolated from activated sludge. Environ Sci Technol 2006;41(2):486-92.

Zhou H, Huang X, Wang X, Zhi X, Yang C, Wen X, et al. Behaviour of selected endocrine-disrupting chemicals in three sewage treatment plants of Beijing, China. Environ Monit Assess 2010;161(1):107-21 